\title{
Effects of cultural treatments, seedling type and morphological characteristics on survival and growth of wild cherry seedlings in Turkey
}

\author{
Derya Esen ${ }^{(1)}$, Oktay Yildiz ${ }^{(1)}$, Ulvi Esen ${ }^{(1)}$, Semih Edis ${ }^{(2)}$, Cengiz \\ Çetintas ${ }^{(3)}$
}

Wild cherry (Prunus avium L.) is receiving increasing attention from foresters in Europe and Turkey for its fast growth, highly-valued wood and benefits for wildlife and biodiversity. Little documentation may be found concerning the selection of appropriate cultural treatments and the quality and types of seedlings used for wild cherry plantations. This study reports the effects of various combinations of intensive cultural treatments (including weed control, soil tillage, and fertilization) and seedling types on early growth, survival, and nutrition of one-year-old wild cherry seedlings out-planted on four different sites in the western Black Sea Region of Turkey. After two years, early seedling survival and growth were clearly enhanced for potted seedlings. For bare-root seedlings, initial seedling root-collar diameter and height successfully correlated with survival two years after planting. Seedlings with a root-collar diameter of $6-8 \mathrm{~mm}$ and height of $60-70 \mathrm{~cm}$ demonstrated the best survival rates in the field. The wild cherry seedlings were shown to be highly sensitive to herbaceous weed competition early in their establishment, warranting effective weed control. When used in addition to weed control, neither intensive fertilization nor soil tillage treatments significantly increased seedling survival and growth two years after planting. Therefore, intensive site preparation, as well as fertilization, are not recommended at this stage for planting sites without severe nutrient deficiencies.

Keywords: Fertilization, Seedling Quality, Tillage, Weed Competition

\section{Introduction}

Reaching up to $1.20 \mathrm{~m}$ in diameter and 35 $\mathrm{m}$ in height, wild cherry (Prunus avium L.) is a fast-growing, broadleaved tree species with a wide natural distribution in both Europe and Turkey. Due to its significant en-

(1) Düzce Üniversitesi Orman Fakültesi (Faculty of Forestry), Düzce (Turkey); (2) Çankiri Karatekin Üniversitesi Orman Fakültesi, Çankiri (Turkey); (3) Abaz mevkii, Tip Fakültesi cad., No:318, D:23, Esenköy, Kozlu, Zonguldak (Turkey).

@ Derya Esen (deryaesen@duzce.edu.tr)

Received: Aug 06, 2012 - Accepted: Nov 05, 2012

Citation: Esen D, Yildiz O, Esen U, Edis S, Çetintas C, 2012. Effects of cultural treatments, seedling type and morphological characteristics on survival and growth of wild cherry seedlings in Turkey. iForest 5: 283-289 [online 2012-1217] URL: http://www.sisef.it/iforest/ contents?id=efor0639-005

Communicated by: Renzo Motta ture of the belt is $14-15^{\circ} \mathrm{C}$, and the average annual rainfall is about $1000 \mathrm{~mm}$ (Atalay 2002).

Similar tree species are associated with wild cherry in natural forests in Europe (especially Germany - Thies et al. 2009) and Turkey. In the western BSR, it grows in the Castanetum phytoclimatic zone at low elevations (Tosun \& Özpay 1988, Atalay 2002, Yaman 2003). Wild cherry is found heavily mixed with sweet chestnut (Castanea sativa Mill.), maples (Acer spp.), European hornbeam (Carpinus betulus L.), eastern beech (Fagus orientalis Lipsky), and ashes (Fraxinus spp.). Scattered occurrences of wild cherry are frequent in the pure eastern beech stands of the Fagetum zones in the region. It is occasionally found with oaks (Quercus spp.) on drier sites (Tosun \& Özpay 1988, Atalay 2002, Yaman 2003). Wild cherry is a shade-intolerant species, making it very sensitive to competition from the surrounding trees. Therefore, shade-tolerant eastern beech frequently outcompetes and displaces wild cherry in natural settings, a situation very similar to that of the wild cherry and European beech (F. sylvatica L.) in Europe (Stojecova \& Kupka 2009).

In addition to high-quality wood production, intensive plantations may help to conserve native forest resources (Donoso et al. 2009). The key characteristics of a successful plantation include appropriate site selection and establishment techniques. Intensive silvicultural treatments accelerate stand development, channel the limited site resources to targeted species and individuals, and reduce rotation periods (Newton et al. 2002). Growing wild cherry in intensively managed plantations can also help reduce Turkey's shortage of quality timber. Although the seed ecology and early seedling growth performances of different seed sources of wild cherry have been studied to a certain extent, no research has been conducted in Turkey so far on the possible survival and growth responses of young wild cherry seedlings to intensive silvicultural treatments (Esen et al. 2005, 2006a, 2009, 2011).

Poor seedling stock can dramatically reduce survival and field performance. Unlike with conifers, there has been little research on the key morphological characteristics associated with the performance of broadleaved tree species following out-planting (Jacobs et al. 2004). Various morphological characteristics, including root-collar diameter, shoot height, and sturdiness ratio (height-to-diameter ratio), are commonly used to evaluate the ability of hardwood seedlings to tolerate environmental and transplanting stresses (Jacobs et al. 2004). Identifying key morphological characteristics improving the survival of young wild cherry seedlings in the first period of establishment will cer- 
Tab. 1 - Locations and geographic data of the study sites in the jurisdiction areas of Bolu and Zonguldak regional forestry directorates in the western Black Sea region of Turkey, where one-year-old Prunus avium seedlings were planted.

\begin{tabular}{|c|c|c|c|c|c|c|}
\hline Site & $\begin{array}{l}\text { Forest } \\
\text { Unit }\end{array}$ & Series & Aspect & $\begin{array}{c}\text { Elevation } \\
\text { (m) }\end{array}$ & $\begin{array}{c}\text { Mean Slope } \\
(\%)\end{array}$ & $\begin{array}{l}\text { Latitudes/ } \\
\text { Longitudes }\end{array}$ \\
\hline Eregli & $\begin{array}{l}\text { Merkez, } \\
\text { Kdz. Ereglisi, } \\
\text { Zonguldak }\end{array}$ & 53 & W-NW & 248 & 19 & $\begin{array}{l}41^{\circ} 18.346^{\prime} \mathrm{N} \\
31^{\circ} 25.454^{\prime} \mathrm{E}\end{array}$ \\
\hline Bendere & $\begin{array}{l}\text { Bendere, } \\
\text { Kdz. Ereglisi, } \\
\text { Zonguldak }\end{array}$ & 75 & $\mathrm{~N}$ & 1100 & 20 & $\begin{array}{l}41^{\circ} 03.667^{\prime} \mathrm{N} \\
31^{\circ} 36.800^{\prime} \mathrm{E}\end{array}$ \\
\hline Akçakoca & $\begin{array}{l}\text { Deredibi, Akçakoca } \\
\text { (Düzce), Bolu }\end{array}$ & $34 b$ & NW & 790 & 2 & $\begin{array}{l}40^{\circ} 59.704^{\prime} \mathrm{N} \\
31^{\circ} 07.504^{\prime} \mathrm{E}\end{array}$ \\
\hline Cumayeri & $\begin{array}{l}\text { Melen (Düzce), } \\
\text { Bolu }\end{array}$ & 223 & - & 145 & 1 & $\begin{array}{l}40^{\circ} 51.802^{\prime} \mathrm{N} \\
30^{\circ} 56.881^{\prime} \mathrm{E}\end{array}$ \\
\hline
\end{tabular}

tainly help ensure a successful plantation.

This study assessed the early effects of various combinations of intensive cultural treatments (including weed control, soil tillage, and fertilization) and seedling types on the survival, growth, and nutrition of oneyear-old wild cherry seedlings planted on four different sites in the western Black Sea Region. The study also focused on the relationships between early seedling survival and various morphological characteristics, including initial diameter, height, and sturdiness ratio.

\section{Materials and methods}

\section{Site description}

The study was carried out on four different sites in the western Black Sea Region (BSR) of Turkey (Tab. 1). Three sites, the Karadeniz Ereglisi (Eregli), Bendere, and Akçakoca (Deredibi) sites, are in recently clear-cut, natural, pure or mixed eastern beech stands located in the vicinity of the Black Sea coast
(Anonymous 2008a, 2008b, Yildiz et al. $2009,2010)$. The overstorey is primarily a closed beech canopy. Sweet chestnut, maples, and wild cherry make up $<10 \%$ of the forest canopy (Anonymous 2008a, 2008b, Yildiz et al. 2009, 2010). The understorey is overgrown with purple-flowered rhododendron (Rhododendron ponticum L.). The average yearly temperature and precipitation are $13^{\circ} \mathrm{C}$ and $1100 \mathrm{~mm}$, respectively (Anonymous 2008a, 2008b, Yildiz et al. 2009, 2010). The fourth location, Cumayeri, is inland and was formerly a degraded oak (Quercus spp.) site. Its average yearly temperature and precipitation are $13^{\circ} \mathrm{C}$ and 840 $\mathrm{mm}$, respectively (Anonymous $2008 \mathrm{c}$ ).

The soils of the three coastal sites are comparatively fertile and well-drained, and vary from sandy loam to clay, whereas the inland site has heavy, clayey soil with low drainage (Anonymous 2008a, 2008b, 2008c, Yildiz et al. 2009, 2010). The standard treatments employed by the General Directorate of Forestry prior to plantings were applied to
Fig. 1 - An illustration of the experimental layout of bare-root (B) and potted (C) one-year-old seedlings of wild cherry out-planted on four different sites in the western Black Sea Region of Turkey.

\begin{tabular}{|c|c|c|c|c|c|c|c|}
\hline \multicolumn{2}{|c|}{$\underbrace{\text { Row Pair }}$} & \multicolumn{2}{|c|}{ Row Pair } & \multicolumn{2}{|c|}{$\overbrace{}^{\text {Row Pair }}$} & \multicolumn{2}{|c|}{ Row Pair } \\
\hline $\mathrm{C}_{1}$ & $\mathrm{~B}_{1}$ & $\mathrm{~B}_{1}$ & $\mathrm{C}_{1}$ & $\mathrm{~B}_{1}$ & $\mathrm{C}_{1}$ & $\mathrm{C}_{1}$ & $\mathrm{~B}_{1}$ \\
\hline $\mathrm{C}_{2}$ & $\mathrm{~B}_{2}$ & $\mathrm{~B}_{2}$ & $\mathrm{C}_{2}$ & $\mathrm{~B}_{2}$ & $\mathrm{C}_{2}$ & $\mathrm{C}_{2}$ & $\mathrm{~B}_{2}$ \\
\hline$C_{3}$ & $\mathrm{~B}_{3}$ & $\mathrm{~B}_{3}$ & $\mathrm{C}_{3}{ }^{3 \mathrm{~m}}$ & $\mathrm{~B}_{3}$ & $C_{3}$ & $C_{3}$ & $\mathrm{~B}_{3}$ \\
\hline $\mathrm{C}_{4}$ & $\mathrm{~B}_{4}$ & $\mathrm{~B}_{4}$ & $\mathrm{C}_{4}$ & $\mathrm{~B}_{4}$ & $\mathrm{C}_{4}$ & $\mathrm{C}_{4}$ & $\mathrm{~B}_{4}$ \\
\hline $\mathrm{C}_{5}$ & $\mathrm{~B}_{5}$ & $\mathrm{~B}_{5}$ & $\mathrm{C}_{5}$ & $\mathrm{~B}_{5}$ & $\mathrm{C}_{5}$ & $\mathrm{C}_{5}$ & $\mathrm{~B}_{5}$ \\
\hline $\mathrm{C}_{6}$ & $\mathrm{~B}_{6}$ & $\mathrm{~B}_{6}$ & $\mathrm{C}_{6}$ & $\mathrm{~B}_{6}$ & $\mathrm{C}_{6}$ & $\mathrm{C}_{6}$ & $\mathrm{~B}_{6}$ \\
\hline$C_{17}$ & $B_{17}$ & $\mathrm{~B}_{17}$ & $\mathrm{C}_{17}$ & $B_{17}$ & $\mathrm{C}_{17}$ & $\mathrm{C}_{17}$ & $B_{17}$ \\
\hline $\mathrm{C}_{18}$ & $B_{18}$ & $\mathrm{~B}_{18}$ & $\mathrm{C}_{18}$ & $\mathrm{~B}_{18}$ & $\mathrm{C}_{18}$ & $\mathrm{C}_{18}$ & $\mathrm{~B}_{18}$ \\
\hline $\mathrm{C}_{19}$ & $B_{19}$ & $\mathrm{~B}_{19}$ & $\mathrm{C}_{19}$ & $\mathrm{~B}_{19}$ & $\mathrm{C}_{19}$ & $\mathrm{C}_{19}$ & $\mathrm{~B}_{19}$ \\
\hline $\mathrm{C}_{20}$ & $\mathrm{~B}_{20}$ & $\mathrm{~B}_{20}$ & $\mathrm{C}_{20}$ & $\mathrm{~B}_{20}$ & $\mathrm{C}_{20}$ & $\mathrm{C}_{20}$ & $\mathrm{~B}_{20}$ \\
\hline $\mathrm{C}_{21}$ & $\mathrm{~B}_{21}$ & $\mathrm{~B}_{21}$ & $\mathrm{C}_{21}$ & $\mathrm{~B}_{21}$ & $\mathrm{C}_{21}$ & $C_{21}$ & $B_{21}$ \\
\hline $\mathrm{C}_{22}$ & $\mathrm{~B}_{22}$ & $\mathrm{~B}_{22}$ & $\mathrm{C}_{22}$ & $\mathrm{~B}_{22}$ & $\mathrm{C}_{22}$ & $\mathrm{C}_{22}$ & $\mathrm{~B}_{22}$ \\
\hline
\end{tabular}

all the sites in preparation for this study. In the fall of 2007, the sites were first raked in a broadcast manner to remove the existing woody vegetation (rhododendrons and oaks). Then, using a bulldozer carrying a brush rake or soil ripper, the sites were ripped down to the first one-meter soil depth in order to promote root growth.

\section{Plant material}

In the late summer of 2006, the Eregli Forest Management Directorate collected seeds from naturally open-grown mature (40 to 50 years-old) wild cherry trees. These trees were scattered throughout Halli and Gümeli $\left(41^{\circ} 05^{\prime} 09^{\prime \prime} \mathrm{N} ; 31^{\circ} 28^{\prime} 00^{\prime \prime} \mathrm{E}\right)$ between 400-800 m a.s.l. in the sub-province of Karadeniz Ereglisi, Zonguldak. Seedlings were grown from seeds under standard nursery practices at the Zonguldak Devrek Forest Nursery $\left(41^{\circ} 13^{\prime} 30^{\prime \prime} \mathrm{N}\right.$; 31 3 $\left.57^{\prime} 35^{\prime \prime} \mathrm{E}\right) \mathrm{du}-$ ring 2007. Seedbeds were irrigated as needed and fertilized monthly between May and August with 18-46-0 diammonium phosphate at the rate of $45 \mathrm{~kg} \mathrm{~N}$ and $115 \mathrm{~kg} \mathrm{P} \mathrm{ha}^{-1}$. Herbaceous weeds growing in the nursery beds were removed by hand monthly during the growing season.

At the end of the growing season, a group of the cherry seedlings were lifted, rootpruned, and then transplanted into 4-L plastic pots. The seedlings were irrigated on an as-needed basis. A month later, a second group of bare-root seedlings were lifted and root-pruned similar to the first group. The roots of these were covered with burlap and kept moist until they were planted. By the end of 2007, all of the potted and bare-root seedlings had been carefully transferred to the experimental sites and planted.

\section{Cultural treatments}

Four treatments, including different combinations of weed control (WC), tillage (T) and fertilization (F), and finally the control (no treatment), were used for the study. For the weed-control treatment (WC), in the early spring of two consecutive years (2008 and 2009), herbaceous vegetation growing within a $50-\mathrm{cm}$ radius of a given seedling stem was completely removed to the bare ground using a hand sickle. The treatment was repeated within the same growing season on an as-needed basis to control weed regrowth.

For the second treatment $(\mathrm{WC}+\mathrm{T})$, the soil within a $50-\mathrm{cm}$ radius of seedlings was hoed by hand in the early spring for two growing seasons. This treatment basically removed the competing vegetation and tilled the soil around the seedlings in one step. As in the WC treatment, weeds that regrew within the same growing season were manually controlled when deemed necessary.

For the last and most intensive treatment $(\mathrm{WC}+\mathrm{T}+\mathrm{F})$, seedlings received the same 
$\mathrm{WC}+\mathrm{T}$ treatment; in addition, subsequent to hoeing, 15-15-15 NPK and triple super phosphate (TSP) fertilizers were applied once by hand to the tilled soil around the seedlings at $275 \mathrm{~kg} \mathrm{ha}^{-1}$ and $138 \mathrm{~kg} \mathrm{ha}^{-1}$ rates, respectively. Successive weed competition that occurred within the same growing season was eliminated manually.

\section{Experimental design and statistical analysis}

A factorial design within a randomized complete block design (RCBD) with four blocks (sites) was used for the experiment. The first experimental factor was the seedling type, occurring at two levels (potted and bare-root), whereas the cultural treatment was the second factor, occurring at four levels initially. However, all seedlings in the control treatment were killed off one year after planting due to severe herbaceous competition. To prevent this fact from swamping any treatment differences between the noncontrol treatments, the data were analyzed without the control treatment, except for the leaf nutrient analysis.

The potted and bare-root wild cherry seedlings were separately planted within two adjacent rows, constituting a row pair (Fig. 1). There were four pairs of seedling rows on each experimental site. The order of the seedling type (bare-root or potted) was randomly determined for each row pair prior to planting. Each row constituted an experimental unit for this study, containing 22-24 potted or bare- root seedlings planted with 3 x $3 \mathrm{~m}$ spacing. In total, 368 potted and 372 bare- root seedlings were planted for the study.

The four experimental treatments were randomly assigned to the four seedling row pairs for each experimental site (Fig. 1). The effects of the seedling type and cultural treatments on seedling survival, growth, and nutrition were analyzed with the two-way analysis of variance (ANOVA). P values $<0.05$ were considered significant. Data were analyzed using the SAS package (SAS Institute Inc 1996).

\section{Measurements}

For each treatment, the seedlings were measured for initial height and root-collar diameter (hereafter termed diameter) at the beginning of the experiment, and re-measured at the end of each growing season for two years. The percent of seedling survival was also determined for each treatment for each growing season. The relative growth rate of the seedlings in each treatment was measured using a formula for the first and second growing seasons (Radosevich et al. 2007 - eqn. 1):

$$
R G R(\%)=\frac{V_{2}-V_{1}}{V_{1}} \cdot 100
$$

Tab. 2 - Effects of various cultural treatments in increasing intensity on mean survival, height, diameter, and relative growth rates of one-year-old Prunus avium seedlings planted in the western BSR of Turkey one and two years after treatments (YAT) with standard errors. (1): treatment $\mathrm{x}$ seedling-type interaction effect was not significant $(\mathrm{p}>0.05)$; (2): due to total seedling mortality, the control treatment was excluded from the analysis; (3): means within the same column within the same year with different letters are significantly different $(\mathrm{p} \leq 0.05)$.

\begin{tabular}{|c|c|c|c|c|c|}
\hline Treatment $^{(1)}$ & $\begin{array}{c}\text { Survival } \\
(\%)\end{array}$ & $\begin{array}{l}\text { Height } \\
\text { (cm) }\end{array}$ & $\begin{array}{l}\text { Diameter } \\
\text { (mm) }\end{array}$ & $\begin{array}{c}\text { Height } \\
\text { Growth } \\
(\%) \\
\end{array}$ & $\begin{array}{c}\text { Diameter } \\
\text { Growth } \\
(\%)\end{array}$ \\
\hline \multicolumn{6}{|l|}{ One YAT } \\
\hline Control (2) & 0 & 0 & 0 & 0 & 0 \\
\hline WC & $77 \pm 4^{\text {a (3) }}$ & $82 \pm 6^{a}$ & $10.2 \pm 0.9^{\mathrm{a}}$ & $122 \pm 23^{a}$ & $96 \pm 19^{a}$ \\
\hline $\mathrm{WC}+\mathrm{T}$ & $86 \pm 4^{\mathrm{a}}$ & $92 \pm 6^{a}$ & $10.8 \pm 0.9^{a}$ & $145 \pm 23^{a}$ & $94 \pm 20^{\mathrm{a}}$ \\
\hline $\mathrm{WC}+\mathrm{T}+\mathrm{F}$ & $82 \pm 3^{a}$ & $87 \pm 4^{\mathrm{a}}$ & $11.2 \pm 0.7^{\mathrm{a}}$ & $142 \pm 18^{a}$ & $102 \pm 15^{a}$ \\
\hline \multicolumn{6}{|l|}{ Two YAT } \\
\hline Control & 0 & 0 & 0 & 0 & 0 \\
\hline WC & $78 \pm 4^{a}$ & $102 \pm 9^{a}$ & $13.9 \pm 1.2^{\mathrm{a}}$ & $214 \pm 37^{a}$ & $160 \pm 23^{a}$ \\
\hline $\mathrm{WC}+\mathrm{T}$ & $83 \pm 3^{a}$ & $111 \pm 9^{a}$ & $14.6 \pm 1.3^{\mathrm{a}}$ & $189 \pm 38^{a}$ & $155 \pm 24^{\mathrm{a}}$ \\
\hline $\mathrm{WC}+\mathrm{T}+\mathrm{F}$ & $78 \pm 3^{a}$ & $107 \pm 7^{\mathrm{a}}$ & $14.8 \pm 0.9^{\mathrm{a}}$ & $216 \pm 29^{a}$ & $171 \pm 18^{a}$ \\
\hline
\end{tabular}

where $R G R$ is the relative growth rate of a seedling from time 1 to time $2 ; V_{1}$ is the seedling diameter $(\mathrm{mm})$ or height $(\mathrm{cm})$ at the beginning of the experiment; $V_{2}$ is the seedling diameter $(\mathrm{mm})$ or height $(\mathrm{cm})$ at the end of the first or second growing season.

For nutrient analysis in the first growing season, 15 seedlings on each seedling row (i.e., experimental unit) were randomly chosen in July 2008 to determine the treatment effects on seedling nutrition. However, only five to eight seedlings could be used for leaf sampling of the control treatment group due to low seedling survival at the time of the sampling. Eight to ten leaves from different crown positions (upper, middle and lower) were collected from each sample seedling. The leaf samples were air-dried, later ground with a coffee grinder. After grinding, leaf samples were dried at $80^{\circ} \mathrm{C}$ and weighed in 100-200-mg aliquots for total $\mathrm{C}$ analysis, and 500-mg aliquots for analysis of $\mathrm{N}$ (Jones \& Case 1990, Yildiz et al. 2010). Leaf C and $\mathrm{N}$ concentrations were determined using a dry combustion method in a LECO CNS 2000 Carbon Analyzer (LECO Corp., St. Joseph, MI - Nelson \& Sommers 1996, Yildiz et al. 2010). For nutrient analysis, plant

tissue samples were digested with a mixture of nitric and perchloric acids (Jones \& Case 1990, Yildiz et al. 2010). Phosphorus concentrations were determined with a Spectronic Colorimeter. $\mathrm{K}$ and $\mathrm{Ca}$ were determined with a Jenway Flame Photometer (Sparks et al. 1996, Yildiz et al. 2010).

\section{Results}

\section{Seedling survival and growth}

One and two years after treatment (YAT), no significant interactions were detected between the cultural treatment and seedling type. Seedling survival, diameter, height, and relative growth rate 1 and 2 YAT did not significantly differ among the cultural treatments (Tab. 2). However, seedling type significantly affected the mean survival rate of the seedlings 1 and 2 YAT (Tab. 3), with the potted seedlings showing almost a $12 \%$ greater survival rate than the bare-root seedlings 1 and 2 YAT. The two seedling types did not dramatically differ in growth variables 1 and 2 YAT, except for second-year diameter. The potted seedlings were almost $35 \%$ greater in diameter than the bare-root seedlings 2 YAT (Tab. 3).

Tab. 3 - Effects of seedling type (potted and bare-root) on mean survival, height, diameter, and relative growth rates of one-year-old Prunus avium seedlings planted in the western BSR of Turkey one and two years after treatment (YAT) with standard errors. (1): treatment $\mathrm{x}$ seedling-type interaction effect was not significant $(\mathrm{p}>0.05)$; (2) means within the same column within the same year with different letters are significantly different $(\mathrm{p} \leq 0.05)$.

\begin{tabular}{lccccc}
\hline $\begin{array}{c}\text { Seedling } \\
\text { Type }^{(\mathbf{1})}\end{array}$ & $\begin{array}{c}\text { Survival } \\
\mathbf{\%}\end{array}$ & $\begin{array}{c}\text { Height } \\
(\mathbf{c m})\end{array}$ & $\begin{array}{c}\text { Diameter } \\
(\mathbf{m m})\end{array}$ & $\begin{array}{c}\text { Height } \\
\text { Growth }(\%)\end{array}$ & $\begin{array}{c}\text { Diameter } \\
\text { Growth }(\%)\end{array}$ \\
\hline $\begin{array}{l}\text { One } Y A T \\
\text { Potted }\end{array}$ & $86 \pm 3^{\mathrm{a}(2)}$ & $88 \pm 4^{\mathrm{a}}$ & $11.4 \pm 0.6^{\mathrm{a}}$ & $147 \pm 17^{\mathrm{a}}$ & $87 \pm 14^{\mathrm{a}}$ \\
Bare-rooted & $77 \pm 3^{\mathrm{b}}$ & $86 \pm 4^{\mathrm{a}}$ & $10.1 \pm 0.6^{\mathrm{a}}$ & $125 \pm 17^{\mathrm{a}}$ & $107 \pm 14^{\mathrm{a}}$ \\
$\begin{array}{l}\text { Two } Y A T \\
\text { Potted }\end{array}$ & & & & & \\
Bare-rooted & $76 \pm 3^{\mathrm{a}}$ & $112 \pm 6^{\mathrm{a}}$ & $16.6 \pm 0.9^{\mathrm{a}}$ & $147 \pm 17^{\mathrm{a}}$ & $181 \pm 17^{\mathrm{a}}$ \\
& 76 & $102 \pm 6^{\mathrm{a}}$ & $12.3 \pm 0.9^{\mathrm{b}}$ & $126 \pm 17^{\mathrm{a}}$ & $142 \pm 17^{\mathrm{a}}$
\end{tabular}


Tab. 4 - Effects of the different cultural treatments in increasing intensity on leaf nutrient concentrations (\%) and C:N ratios of one-year-old Prunus avium seedlings planted in the western BSR of Turkey one year after treatment. (1): treatment $\mathrm{x}$ seedling-type interaction effect was not significant ( $p>0.05)$; (2): means within the same column with different letters are significantly different $(\mathrm{p} \leq 0.05)$.

\begin{tabular}{lllllll}
\hline Treatment $^{(\mathbf{1})}$ & $\mathbf{C}$ & $\mathbf{N}$ & $\mathbf{C}: \mathbf{N}$ & $\mathbf{P}$ & $\mathbf{K}$ & $\mathbf{C a}$ \\
\hline Control & $48.2^{\mathrm{a}(2)}$ & $2.14^{\mathrm{b}}$ & $26^{\mathrm{a}}$ & $0.33^{\mathrm{a}}$ & $1.08^{\mathrm{a}}$ & $1.07^{\mathrm{a}}$ \\
WC & $47.9^{\mathrm{a}}$ & $2.11^{\mathrm{b}}$ & $24^{\mathrm{a}}$ & $0.29^{\mathrm{a}}$ & $1.10^{\mathrm{a}}$ & $1.02^{\mathrm{a}}$ \\
WC $+\mathrm{T}$ & $48.0^{\mathrm{a}}$ & $2.43^{\mathrm{ab}}$ & $20^{\mathrm{ab}}$ & $0.32^{\mathrm{a}}$ & $1.08^{\mathrm{a}}$ & $0.91^{\mathrm{a}}$ \\
WC $+\mathrm{T}+\mathrm{F}$ & $48.0^{\mathrm{a}}$ & $2.73^{\mathrm{a}}$ & $18^{\mathrm{b}}$ & $0.34^{\mathrm{a}}$ & $1.08^{\mathrm{a}}$ & $1.02^{\mathrm{a}}$ \\
\hline
\end{tabular}

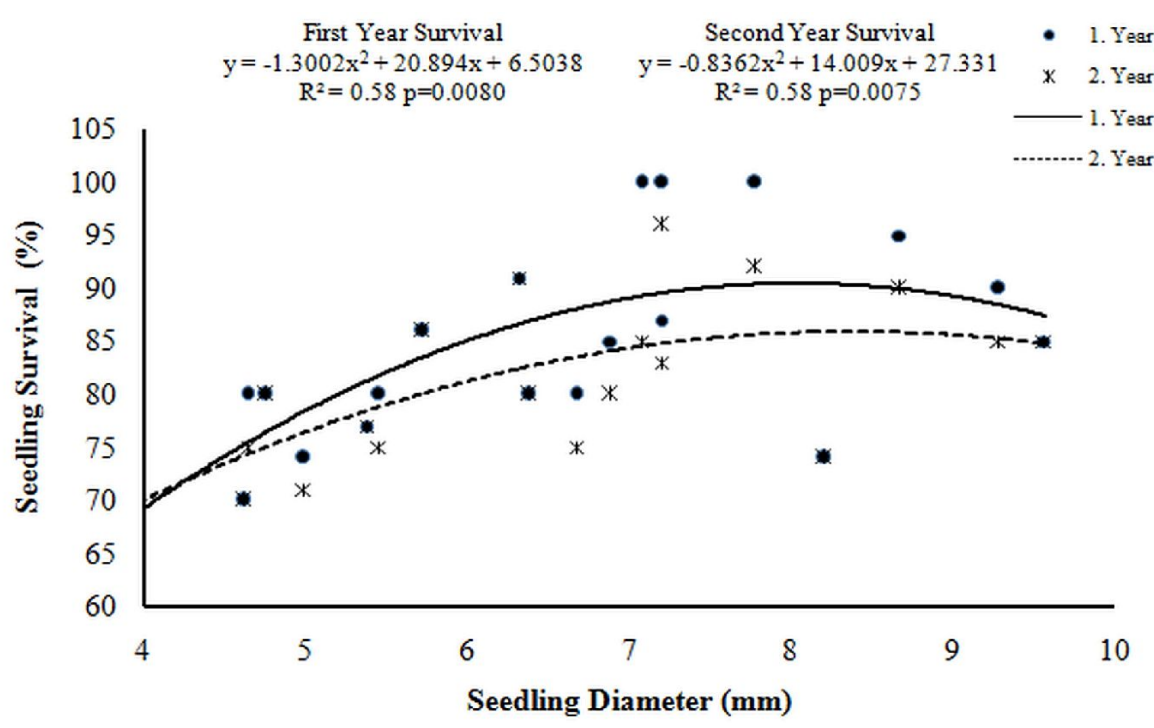

Fig. 2 - Relationship between mean seedling survival rate (\%) and initial seedling diameter $(\mathrm{mm})$ for one-year-old wild cherry seedlings planted on four sites in the western Black Sea Region of Turkey one and two years after planting with regression equation, Pearson correlation coefficient, and significance level.

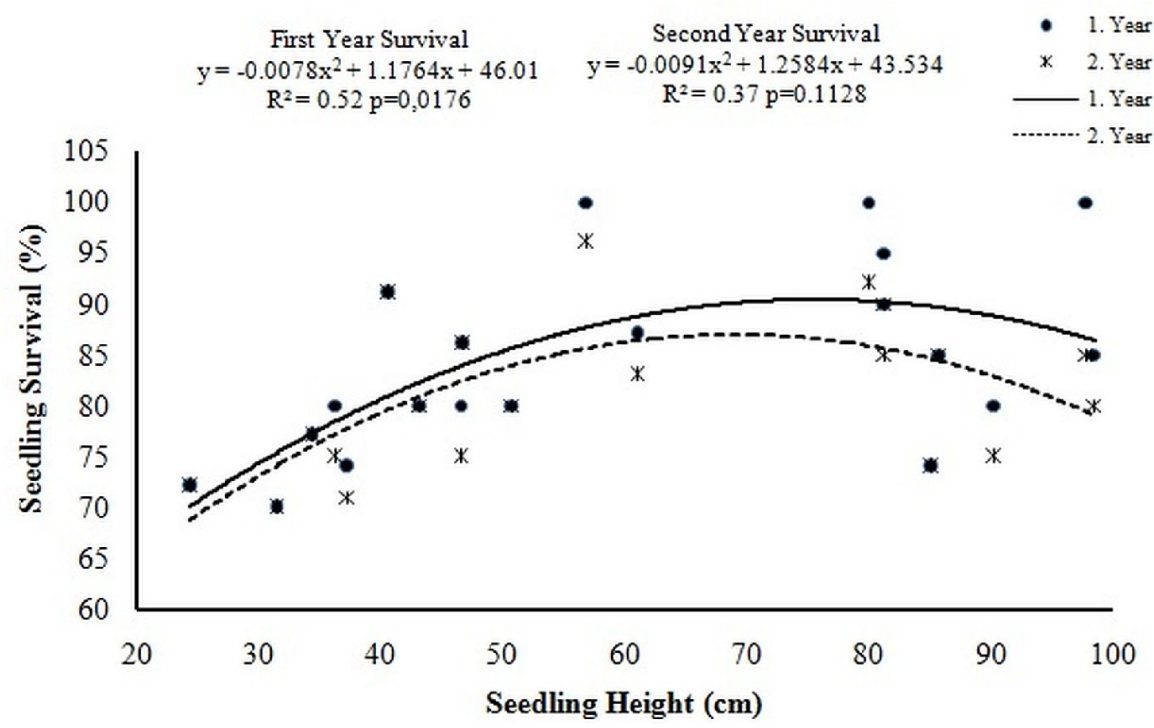

Fig. 3 - Relationship between mean seedling survival rate (\%) and mean initial seedling height $(\mathrm{cm})$ for one-year-old wild cherry seedlings planted on four sites in the western Black Sea Region of Turkey one and two years after planting with regression equation, Pearson correlation coefficient, and significance level.

\section{Leaf nutrient analysis}

Similar to the findings of the survival and growth data, no significant interactions between the cultural treatment and seedling type were found for leaf nutrient analysis (Tab. 4). The seedling type had no significant effect on the concentrations of the leaf nutrients analyzed. Also, the effects of various cultural treatments, including the control, on leaf $\mathrm{C}, \mathrm{P}, \mathrm{K}$, and $\mathrm{Ca}$ concentrations were not significantly different. However, the seedlings with the most intensive cultural treatment $(\mathrm{WC}+\mathrm{T}+\mathrm{F})$ had a significantly greater $(28 \%)$ leaf $\mathrm{N}$ concentration compared to the seedlings of the $\mathrm{WC}$ and control group (Tab. 4). The seedlings with the $\mathrm{WC}+\mathrm{T}+\mathrm{F}$ treatment had the lowest $\mathrm{C}: \mathrm{N}$ ratio among those of all treatments. The mean leaf C:N ratios of the control and $\mathrm{WC}$ seedlings were significantly greater $(33 \%$ and $44 \%$, respectively) than those of the $\mathrm{WC}+\mathrm{T}$ and $\mathrm{WC}+\mathrm{T}+\mathrm{F}$ seedlings (Tab. 4).

\section{Seedling morphological characteristics}

Among the three non-control cultural treatments, there were no statistically significant variations for seedling survival and growth 1 and 2 YAT. The relationships between the morphological characteristics and the survival of the bare-root seedlings were assessed using additional correlation and regression analysis. Relationships of the first- and second-year survival of the bare-root seedlings to the initial diameter, height, and height-to-diameter ratios were determined using simple regression and correlation analysis. Second-order regressions described the curvilinear relations of the initial diameter, height, and sturdiness ratio of the bare-root wild cherry seedlings with seedling survival 1 and 2 YAP (Fig. 2, Fig. 3).

The seedling diameters demonstrated a significant positive relationship with survival 1 and 2 YAP, with relatively high correlation coefficients (Fig. 2). First- and secondyear seedling survival rates increased almost linearly with increasing seedling diameter up to diameters of 7-8 $\mathrm{mm}$, yet tended to decline above this diameter range (Fig. 2).

Similarly to the first-year results for diameter, seedling height demonstrated a significant relationship with seedling survival 1 YAP (Fig. 3). Seedling survival increased with increasing height up to $60-70 \mathrm{~cm}$, after which the relationship gradually turned negative. However, these two variables had no significant relationship 2 YAP (Fig. 3). Finally, the relationships between the sturdiness ratio and survival for both one- and two-year-old seedlings were not significant.

\section{Discussion and conclusions}

Wild cherry has a high demand for light, soil water, and nutrients; therefore, the species is highly sensitive to herbaceous weed competition in the first three years of esta- 
blishment (Savill 1991, Joyce et al. 1998, Kupka 2002, Esen et al. 2006b). Unwanted vegetation substantially reduces the growth and survival of young cherry seedlings during establishment (Kupka 2002, Löf et al. 2004, Esen et al. 2006b). This was clearly confirmed by the present study, which had total seedling mortality in the control treatment group (Tab. 2). Elimination of competing vegetation is therefore an important requisite to producing wild cherry individuals with diameters of $50-60 \mathrm{~cm}$ in a $50-$ to 60 year rotation (Joyce et al. 1998, Nicolescu \& Nicolescu 2002). However, the present study has shown that neither fertilization nor soil cultivation, nor a combination of the two performed as well as weed control in terms of additional survival and growth in the first two years (Tab. 2); therefore, they are not recommended. Similar results were obtained in Latvia (Daugaviete 2000) and in the Czech Republic (Dostalek et al. 2007), where various intensive cultural treatments, including mechanical and chemical weed control and tillage, did not produce significant growth differences for young wild cherry seedlings in the first three and five years following planting.

There are contradictory results in the previous studies of the effects of fertilization on the seedlings of broadleaved tree species (Jacobs et al. 2005). One group of these studies states that fertilization increases the seedling growth of broadleaved tree species (Chang 2003, Jacobs et al. 2004, 2005, Scowcroft \& Silva 2005). However, another group reported that fertilization during the early establishment period does not have a major sustainable effect on tree seedling growth (Duryea \& Dougerthy 1991, Löf \& Welander 2004, Jacobs et al. 2005, Donoso et al. 2009) and is actually detrimental in some cases (Jacobs et al. 2005). The results of the present study were consistent with the findings of the second group.

The foliar nutrient levels of the cherry seedlings in the present study are similar to those of young eastern beech seedlings reported in previous studies that were carried out in the mesic, coastal part of the western BSR (Yildiz et al. 2009, 2010). Based on foliar analysis of the present study, as well as the survival and growth data, we found no substantial evidence that added nutrients had a significant effect on the cherry seedlings, except for $\mathrm{N}$ (Tab. 2, Tab. 4), and this was not substantiated by the survival and growth data. The lack of effects of fertilization on cherry survival, growth, and nutrition suggests that the productivity of the experimental site was adequate. The mesic and coastal sites of the western BSR, where threefourths of this experiment were carried out, are well known for their relatively high productivity (Atalay 2002, Yildiz et al. 2010) The present case demonstrates that costly site operations, including fertilization, should be thoroughly justified before being applied to cherry planting sites. However, one should remember that these are early assessments and may change with future longterm data.

In the present study, the Cumayeri site was characterized by two extreme edaphic conditions. The soil was mostly waterlogged during the winter, whereas the water table fell quickly during the summer, leaving very dry and hard-to-penetrate soil. The lowest seedling survival and growth occurred on this site (data not shown), suggesting that soil moisture and aeration are essential and even more critical than soil nutrients for wild cherry survival and growth (Savill 1991, Higgs et al. 1995, Russell 2003). These findings present the opportunity to test the effect of plowing as an option for site preparation. Previous experiments have demonstrated that plowing may enhance soil drainage, weed control, and root growth of tree seedlings, enabling the establishment of broadleaved tree plantations in clay soil (Kätterer et al. 1995, Ponti et al. 2004).

Care should be taken with total plantations of wild cherry, since they are more susceptible to diseases than mixed plantations (Spiecker 1994). Mixing wild cherry with other broadleaved tree species, including ash (F. excelsior L.), is in fact recommended for enhanced productivity and disease control (Kerr 2004).

The superiority of potted seedlings over bare-root seedlings for tree seedling survival and growth is well documented (Wilson \& Jacobs 2006, Haase 2007). The results of the present study were consistent with this finding (Tab. 4). The bare-root seedlings of broadleaved tree species commonly undergo a transplant shock, mostly due to drought and nutrient deficiency experienced following planting (Struve \& Joly 1992). The soil column surrounding the root system of potted seedlings protects them from environmental stresses (e.g., drought, freezing-thawing cycles, and transplant shock) and physical stresses (e.g., abrasion, crushing, and root stripping). Additionally, in the spring, the constant contact of the root with the soil might physiologically activate potted seedlings earlier than the bare-root seedlings, improving survival and growth (Rietveld 1989, Jacobs et al. 2004, Jacobs et al. 2005, Haase 2007).

Using high-quality seedlings is an important prerequisite for successful plantation. The initial diameter has been reported to be the trait that was most significantly and positively related to early field survival and growth performance for many broadleaved tree species (Dey \& Parker 1997, Jacobs et al. 2004). For example, in one Canadian study (Dey \& Parker 1997), one-year-old red oak (Quercus rubra L.) seedlings with large initial diameters $(>8-10 \mathrm{~mm})$ exhibited greater growth than those with smaller diameters. The present study corroborated this for wild cherry, yet with a size limit (Fig. 2). The diameter corresponds closely with above- and below-ground features, including root volume, area, and biomass, that are correlated with the success of seedlings after outplanting (Dey \& Parker 1997, Jacobs et al. 2004). Also, greater diameters indicate greater carbon storage and energy for broadleaved seedlings, thus enhancing survival until seedlings begin harvesting resources from the soil following outplanting (Jacobs 2003). In the present study, the tendency of seedling survival to decline above a certain diameter range $(7-8 \mathrm{~mm})$ for wild cherry (Fig. 2) might suggest "the lack of balance in larger seedlings" (Thompson 1985).

Seedling height defines the photosynthetic and transpiration capability of seedlings and their competitiveness against weeds, and thus correlates well with seedling growth (Jacobs 2003, Haase 2007). Kupka (2001) stated that the initial height is a good estimate of wild cherry seedling survival during establishment. As they are sensitive to weed competition, young wild cherry seedlings that are taller can gain a substantial advantage over competing vegetation (Kupka 2001). Similar to findings of the present study (Fig. 3), the curvilinear relation of the initial height with survival has been reported for $Q$. serrata Murray and $Q$. acutissima Carruth. (Matsuda 1989, Hashizume \& Han 1993, respectively). Hashizume \& Han (1993) found that the survival of oak seedlings increased with initial height up to 100 $\mathrm{cm}$, yet gradually declined for seedlings taller than $150 \mathrm{~cm}$.

For successful wild cherry plantations, the quality and type of seedlings are important. Potted seedlings are to be preferred to bareroot seedlings for enhanced early survival and growth. Initial seedling diameter and height are effective indicators of early seedling survival. Selecting seedlings for planting of approximately $8 \mathrm{~mm}$ in diameter and $70 \mathrm{~cm}$ in height is therefore recommended for greater survival of bare-root seedlings of this broadleaved tree species.

Finally this study has been focused on the early development and on a short period of time; further work and long-term data are needed to confirm the results.

\section{Acknowledgments}

This work was supported by the Scientific and Technical Research Council of Turkey (TÜBITAK - grant number TOVAG COST 106O817). We thank the Bolu and Zonguldak Regional Directorates of Forestry of the General Directorate of Forestry, the Turkish Ministry of Environment and Forestry, for access to research sites and for their other 
support in this work. We also thank Mrs. K. C. Hollandsworth and Nuriye Peachy for editing this paper for English. Lastly, we express appreciation to all of the anonymous reviewers who took part in the revision process of this manuscript for making important contributions.

\section{References}

Anonymous (2008a). Zonguldak Orman Bölge Müdürlügü Karadeniz Ereglisi Orman Isletme Müdürlügü Amenajman Plani (2008-2027). Orman Genel Müdürlügü, Ankara, Turkey.

Anonymous (2008b). Bolu Orman Bölge Müdürlügü Akçakoca Orman Isletme Müdürlügü Amenajman Plani (2008-2027). Orman Genel Müdürlügü, Ankara, Turkey.

Anonymous (2008c). Bolu Orman Bölge Müdürlügü Düzce Orman Isletme Müdürlügü Amenajman Plani (2008-2027). Orman Genel Müdürlügü, Ankara, Turkey.

Atalay I (2002). Türkiye'nin Ekolojik Bölgeleri. Orman Bakanlangi Yayinlari, No. 163, Ankara, Turkey.

Chang CX (2003). Seedling sweetgum ( $\mathrm{Li}$ quidambar styraciflua L.) half-sib family response to $\mathrm{N}$ and $\mathrm{P}$ fertilization: growth, leaf area, net photosynthesis and nutrient uptake. Forest Ecology and Management 173(13): 281-291. doi: 10.1016/S0378-1127(02)00007-5

Daugaviete M (2000). Afforestation of agricultural lands in Latvia. In: Proceedings of the scientific symposium on "NEWFOR - New Forests for Europe: afforestation at the turn of the century" (Weber $\mathrm{N}$ ed). Freiburg (Germany), 16-17 February 2000, pp. 175-186.

Dey DC, Parker WC (1997). Morphological indicators of stock quality and field performance of red oak (Quercus rubra L.) seedlings underplanted in a Central Ontario Shelterwood. New Forests 14: 145-156. - doi: 10.1023/A:1006577 201244

Donoso PJ, Soto DP, Schlatter JE, Büchner CA (2009). Effects of early fertilization on the performance of Nothofagus dombeyi planted in the coastal range of south-central Chile. Ciencia E Investigación Agraria 36 (3): 475-486. - doi: 10.4067/S0718-16202009000300014

Dostalek J, Weber M, Matula S, Frantik T (2007). Forest stand restoration in the agricultural landscape: the effect of different methods of planting establishment. Ecological Engineering 2 (9): $77-$ 86. - doi: 10.1016/j.ecoleng.2006.07.016

Duryea ML, Dougerthy PH (1991). Forest regeneration manual. Kluwer Academic Publishing, Dordrecht, the Netherlands.

Esen D, Yildiz O, Kulaç S, Sarginci M (2005). Türkiye ormanlarinin ihmal edilen degerli yaprakli türü yabani kiraz. TMMOB Orman Mühendisleri Odasi Dergisi 4.5.6: 18-22. [online] URL: http://dergi.ormuh.org.tr/20052sy/ ykiraz.htm

Esen D, Yildiz O, Çiçek E, Kulaç S, Kutsal Ç (2006a). Effects of different pretreatments on the germination of different wild cherry (Prunus avium L.) seed sources. Pakistan Journal of Bo- tany 38 (3): 735-744. [online] URL: http://www. pakbs.org/pjbot/PDFs/38\%283\%29/PJB38\%283 \%29735.pdf

Esen D, Yildiz O, Gunes N, Sarginci M (2006b). Early susceptibility of hardwood tree seedlings to different post-emergent herbicides. Journal of Balkan Ecology 9 (2): 161-166.

Esen D, Günes N, Yildiz O (2009). Effects of citric acid presoaking and stratification on germination behavior of Prunus avium L. seeds. Pakistan Journal of Botany 41(5): 2529-2535. [online] URL: http://www.pakbs.org/pjbot/PDFs/ 41(5)/PJB41(5)2529.pdf

Esen D, Yildiz O, Kulaç S, Çiçek E, Çetintas C, Çetin B, Günes N, Kutsal C (2011). Early growth performances of various seed sources of black (Prunus serotina Erhr.) and wild cherry (Prunus avium L.) seedlings on low and high elevation sites in the western Black Sea Region of Turkey. African Journal of Biotechonology 10 (9): 1566-1572. - doi: 10.5897/AJB10.1706

Haase DL (2007). Morphological and physiological evaluations of seedling quality. In: Proceedings of the conference "Forest and Conservation Nursery Associations - 2006" (Riley LE, Dumroese RK, Landis TD eds). RMRS-P-50, USDA Forest Service, Rocky Mountain Research Station, Fort Collins, CO, USA, pp. 3-8. [online] URL: http://www.fs.fed.us/rm/pubs/ rmrs_p050/rmrs_p050_003_008.pdf

Hashizume H, Han H (1993). A study on forestation using large-size Quercus acutissima seedlings. Hardwood Research 7:1-22

Hemery G, Spiecker H, Aldinger E, Kerr G, Collet C, Bell S (2008). Growing valuable broadleaved tree species. Cost Action E42, Final Report. [online] URL: http://w3.cost.eu/fileadmin/domain files/FFP/Action_E42/final_report/final_reportE42.pdf

Higgs KH, Hipps NA, Collard LG (1995). Effects of irrigation and nitrogen-fertilization on the water relations of Prunus avium and Colt (Prunus avium $\mathrm{L} \times$ P. pseudocerasus $\mathrm{L}$ ) in the nursery, and residual effects after outplanting. The Journal of Horticultural Science and Biotechnology 70 (2): 235-244.

Jacobs DF (2003). Nursery production of hardwood seedlings. Planting and care of fine hardwood seedlings. FNR-212, NEW 9/03, USDA Forest Service, USA, pp. 8. [online] URL: http://www.ncrs.fs.fed.us/pubs/jrnl/2003/nc 200 3 jacobs_001.pdf

Jacobs DF, Wilson BC, Davis AS (2004). Recent trends in hardwood seedling quality assessment. In: Proceedings of the conference "Forest and Conservation Nursery Associations - 2006" (Riley LE, Dumroese RK, Landis TD eds). RMRS-P-33, USDA Forest Service, Rocky Mountain Research Station, Fort Collins, CO, USA, pp. 140-144 [online] URL: http://www.rngr.net/ publications/proceedings/2003/PDF.2004-0608.4952

Jacobs DF, Salifu KF, Seifert JR (2005). Growth and nutritional response of hardwood seedlings to controlled-release fertilization at outplanting. Forest Ecology and Management 214 (1-3): 28-
39. - doi: 10.1016/j.foreco.2005.03.053 Jones JB, Case VW (1990). Sampling, handling and analyzing plant tissue samples. In: "Soil testing and plant analysis" (Westerman RL, Baird JV, Christensen NW, Fixen PE, Whitney DA eds). Soil Science Society of America, Madison, Wisconsin, USA, pp. 389-427.

Joyce PM, Huss J, McCarthy R, Pfeifer A, Hendrick E (1998). Growing broadleaves - silvicultural guidelines for ash, sycamore, wild cherry and oak in Ireland. COFORD, Dublin, Ireland. [online] URL: http://www.coford.ie/media/ coford/content/publications/projectreports/coford connects/Silviculture_Of_Broadleaves.pdf

Kätterer T, Fabiao A, Madeira M, Riberio C, Steen E (1995). Fine-root dynamics, soil moisture and soil carbon content in a Eucalyptus globulus plantation under different irrigation and fertilisation regimes. Forest Ecology and Management 74 (1-3): 1-12. - doi: 10.1016/0378-1127 (95)03529-J

Kerr G (2004). The growth and form of ash (Fraxinus excelsior) in mixture with cherry (Prunus avium), oak (Quercus petraea and Quercus robur), and beech (Fagus sylvatica). Canadian Journal of Forest Research 34:23402350. - doi: 10.1139/x04-113

Kupka I (2001). Influence of different treatment on wild cherry seedling performance. Journal of Forest Science 47 (11): 486-491. [online] URL: http://iris.env.cz/ris/ekodisk-new.nsf/3c715bb7027b1c65c1256bb3007b7af2/961719ee2084b 79ac1256e6a004f7f6c/\$FILE/Journal\%20of $\% 20$ Forest $\% 20$ Science $\% 202001$ -

11.pdf\#page $=12$

Kupka I (2002). Preliminary results of wild cherry plantation under weed competition. In: Proceedings of the conference "The management of valuable broadleaved forests in Europe". Freiburg (Germany), May 2002, pp. 13-14.

Löf M, Welander NT (2004). Influence of herbaceous competitors on early growth in direct seeded Fagus sylvatica L. and Quercus robur L. Annals of Forest Science 61: 781-788. - doi: 10.1051/forest:2004075

Löf M, Thomsen A, Madsen P (2004). Sowing and transplanting of broadleaves (Fagus sylvatica L., Quercus robur L., Prunus avium L., and Crataegus monogyna Jacq.) for afforestation of farmland. Forest Ecology and Management 188: 113-123. - doi: 10.1016/j.foreco.2003.07.013

Matsuda K (1989). Survival and growth of konara oak (Quercus serrata Thunb.) seedlings in an abandoned coppice forest. Ecological Research 4 (3): 309-321. - doi: 10.1007/BF02348451

Nelson DW, Sommers LE (1996). Total carbon, organic carbon, and organic matter. In: "Methods of soil analysis" (Sparks DL, Page AL, Helmke PA, Loepert RH, Soltanpour PN, Tabatabai MA, Johnston CT, Sumner ME eds). Soil Science Society of America / American Society of Agronomy, Madison, Wisconsin, USA, pp. 961-1010.

Newton LP, Robison DJ, Hansen G, Allen HL (2002). Fertilization thinning in a 7-year-old natural hardwood stand in eastern North Carolina. 
Gen. Tech. Rep. SRS-48, USDA Forest Service, Southern Research Station, Asheville, NC, USA, pp. 193-195.

Nicolescu NV, Nicolescu D (2002). Silviculture of wild cherry (Prunus avium L. Syn Cerasus avium (L.) Moench), between ecological and technological requirements and defects (rots and green lines). Revista Padurilor 5: 4.

Ponti F, Minotta G, Cantoni L, Bagnaresi U (2004). Fine root dynamics of pedunculate oak and narrow-leaved ash in a mixed-hardwood plantation in clay soils. Plant and Soil 259 (1-2) 39-49. - doi: 10.1023/B:PLSO.0000020949. 61458.76

Radosevich SR, Holt J, Ghersa CM (2007). Ecology of weeds and invasive plants. Relationship to agriculture and natural resource management ( $3^{\text {rd }}$ edn). John Wiley and Sons Inc., New York, USA.

Rietveld R (1989). Transplanting stress in bareroot conifer seedlings: its development and progression to establishment. Northern Journal of Applied Forestry 6: 99-107.

Russell K (2003). EUFORGEN technical guidelines for genetic conservation and use for wild cherry (Prunus avium). International Plant Genetic Resources Institute, Rome, Italy. [online] URL: $\quad$ http://www.euforgen.org/fileadmin/bio versity/publications/pdfs/859_Technical_guideli nes_for_genetic_conservation_and_use_for_Wil d cherry Prunus avium .pdf

SAS Institute Inc (1996). SAS/STAT users guide, Version 6.12. SAS Institute, Cary, North Carolina, USA.

Savill PS (1991). The Silviculture of trees used in British Forestry. CAB International, Oxon, UK
Savill PS, Kerr G, Kotar M (2009). Future prospects for the production of timber fromvaluable broadleaves. In: "Valuable broadleaved forests in Europe" (Spiecker H, Hein S, MakkonenSpiecker K, Thies M eds). EFI Research Reports vol. 22. Brill Leiden, Boston, USA, pp. 11-26. Scowcroft PG, Silva JA (2005). Effects of phosphorus fertilization, seed source, and soil type on growth of Acacia koa. Journal of Plant Nutrition 28 (9): 1581-1603. - doi: 10.1080/01904160500 203473

Sparks DL, Page AL, Helmke PA, Loeppert RH, Soltanpour PN, Tabatabai MA, Johnson CT, Sumner ME, Bartels JM, Bigham JM (1996). Methods of soil analysis - Part 3 - Chemical methods. Soil science society of America Inc. and American Society of Agronomy Inc. Madison, Wisconsin, USA.

Spiecker M (1994). Wachstum und Erziehung wertvoller Waldkirschen. Mitteilungen der FVA Baden-Wurttemberg, Germany, pp. 181.

Stojecova R, Kupka I (2009). Growth of wild cherry (Prunus avium L.) in a mixture with other species in a demonstration forest. Journal of Forest Science 55 (6): 264-269. [online] URL: http://www.agriculturejournals.cz/publicFiles/06 925.pdf

Struve DK, Joly RJ (1992). Transplanted red oak seedlings mediate transplant shock by reducing leaf surface area and altering carbon allocation. Canadian Journal of Forest Research 22: 14411448. - doi: 10.1139/x92-194

Thies M, Hein S, Spiecker H (2009). Results of a questionnaire on management of valuable broadleaved forests in Europe. In: "Valuable broadleaved forests in Europe" (Spiecker H,
Hein S, Makkonen-Spiecker K, Thies M eds). EFI Research Reports, vol. 22. Brill Leiden, Boston, USA, pp 27-42.

Thompson BE (1985). Seedling morphological evaluation - What you can tell by looking? In: Proceedings on "Evaluating seedling quality: principles, procedures, and predictive abilities of major tests" (Duryea ML ed). Oregon State University, Corvallis (OR - USA) 16-18 October 1984, pp. 59-71.

Tosun S, Özpay Z (1988). Klonal silvikültürde ümit vaad eden bir agaç türü: Kiraz (Prunus avium L.). TMMOB Orman Mühendisleri Odasi Dergisi 10: 17-20.

Wilson BC, Jacobs DF (2006). Quality assessment of temperate zone deciduous hardwood seedlings. New Forests 31 (3): 417-433. - doi: 10.1007/s11056-005-0878-8

Yaman B (2003). Yabani kiraz (Cerasus avium (L.) Moench), GÜ-Orman Fakültesi Dergisi 3 (1): 114-122

Yildiz O, Esen D, Sarginci M (2009). Long-term site productivity effects of different rhododendron control methods in eastern beech (Fagus orientalis Lipsky) ecosystems in the western Black Sea region of Turkey. Soil Use and Management 25 (1): 28-33. - doi: 10.1111/j.14752743.2008.00190.x

Yildiz O, Esen D, Karaöz O, Sarginci M, Toprak B, Soysal Y (2010). Effects of different site preparation methods on soil carbon and nutrient removal from eastern beech regeneration sites in Turkey's Black Sea region. Applied Soil Ecology 45: 49-55. - doi: 10.1016/j.apsoil.2010.01.007 